\title{
GAMBARAN ANEMIA PADA LANJUT USIA DI PANTI SOSIAL TRESNA WERDHA ABIYOSO YOGYAKARTA TAHUN 2013
}

\author{
Hieronymus Rayi Prasetya ${ }^{1}$, Sistiyono ${ }^{2}$, Maria Elisabeth Enjel Naur ${ }^{3}$ \\ ${ }^{1}$ STIKes Guna Bangsa Yogyakarta, ${ }^{2}$ Poltekkes Kemenkes Yogyakarta, \\ ${ }^{3}$ STIKes Guna Bangsa Yogyakarta
}

\begin{abstract}
Background: Anemia is a main health problem of elderly. The aging process causes many psychological changes in nearly all body systems of elderly that causes many kinds of processes of nutrient absorptions in the body disturbed. There is an opinion says that generally elderly has lower hemoglobin levels compared to the younger people. Other research showed that elderly often suffered from calorie and protein malnutrition and micronutrient. It happened because the HCL and pepsin secretion was reduced. Consequently, the absorption of Vitamin B12 and iron decreased that causes Anemia.

Method: It was a descriptive analysis with laboratory tests. The sample of this research was 60 yearold and older patients in TresnaWerdhaAbiyoso Nursing Home Yogyakarta. There were 96 patients. The data of research results were analyzed descriptively and presented in the forms of tables and graphs.

Results: Of the 96 old patients, there were 31 patients suffered from anemia that consisted of 27 patients with mild anemia and 10 patients with moderate anemia. Based on the morphology of erythrocytes in elderly, there were two kinds of anemia. They were normocytic-normochromic anemia with 84 patients and microcytic-hypochromic anemia with 12 patients.

Conclusion: The description of anemia in elderly who stayed in TresnaWerdhaAbiyoso Nursing Home Yogyakarta showed that $32.29 \%$ of the elderly suffered from anemia. $72.97 \%$ suffered from mild anemia. $27.03 \%$ suffered from moderate anemia. The anemia classifications based on morphology in elderly in TresnaWerdhaAbiyoso Nursing Home Yogyakarta were 87.5\% normocyticnormochromic anemia and $12.5 \%$ microcytic-hypochromic anemia.
\end{abstract}

Key words: Anemia, Elderly, Nursing home.

\section{PENDAHULUAN}

Anemia merupakan masalah kesehatan yang paling utama pada lansia. Namun, anemia sebaiknya tidak dianggap sebagai konsekuensi penuaan yang tidak dapat dihindari. Anemia pada lansia menandakan adanya suatu penyakit yang mendasari. Anemia Defisiensi Besi (ADB) merupakan salah satu penyebab utama anemia pada lansia, karena pada umumnya lanjut usia kurang efisien dalam menyerap beberapa nutrisi penting, selain itu, menurunnya nafsu makan karena penyakit yang dideritanya, kesulitan menelan karena berkurangnya air liur, cara makan yang lambat karena penyakit pada gigi, gigi yang berkurang dan mual karena masalah depresi, hal ini menyebabkan defisiensi zat besi pada tubuh lansia

Secara umum populasi usia lanjut memiliki kadar hemoglobin yang lebih rendah dibandingkan pada usia yang lebih muda.. Secara individual penurunan kadar hemoglobin dianggap sebagai proses normal karena bertambahnya usia tetapi penyakit memiliki kontribusi terhadap perkembangan dari anemia tersebut (Bahtari, 2010).

Menurut NHANES III, penyebab anemia pada usia lanjut anatara lain; a) anemia yang berhubungan dengan perdarahan/kekurangan nutrisi (34\%); b) anemia yang berhubungan dengan penyakit kronis/inflamasi atau penyakit ginjal kronik (32\%); c) anemia yang tidak diketahui penyebabnya (34\%).

Berdasarkan Data Direktorat Pelayanan Sosial Lanjut Usia panti werdha di Yogyakarta yang memiliki populasi pasien terbesar adalah PSTW Abiyoso. Oleh karena itu Peneliti ingin melakukan penelitian mengenai Gambaran Anemia Pada Lanjut Usia di Panti Sosial Tresna Werdha Abiyoso Yogyakarta, Gambaran anemia yang dimaksud disini adalah prefalensi anemia pada lansia di PSTW Abiyoso Yogyakarta. Prefalensi yang nantinya akan diperoleh dapat ditentukan derajat anemianya baik ringan, 
sedang maupun berat dan akan iklasifikasikan berdasarkan morfologi eritrositnya.

\section{METODE PENELITIAN}

Jenis penelitian ini termasuk jenis penelitian Deskriptif.. Dalam penelitian deskriptif terdapat dua kelompok data yaitu data kualitatif dan data kuantitatif. Data kualitatif menggambarkan dengan kata-kata atau kalimat sedangkan data kuantitatif berwujud angka-angka hasil perhitungan atau pengukuran (Arikunto, 1998).

Populasi penelitian ini meliputi lanjut usia yang berusia 60 tahun ke atas di Panti Sosial Tresna Werdha ABIYOSO Yogyakarta. Teknik pengumpulan sampel dengan Proporsi Random Sampling dengan jumlah sampel 96 orang. Proses pengumpulan data dilakukan dalam tiga tahap yaitu tahap persiapan berupa observasi dan wawancara, pelaksanaan berupa pemilihan sampel dan pemeriksaan kadar Hemoglobin, nilai Hematokrit, jumlah Eritrosit, MCV, MCH, MCHC dengan matode automatic analyzer serta tahap penyelesaian.
Data yang diperoleh kemudian dianalisis dengan mengkategorian lansia yang anemia berdasarkan morfologi dan berdasarkan derajat anemia sesuai dengan acuan yang dipakai yaitu berdasarkan DEPKes RI. Data penelitian disajikan dalam bentuk diagram

\section{HASIL DAN PEMBAHASAN}

A. Hasil

\section{Gambaran Responden}

Penelitian ini meliputi 96 sampel. Sampel yang didapatkan merupakan pasien di Panti Sosial Tresna Werdha Abiyoso

Yogyakarta. Sebagian besar sampel adalah perempuan dengan jumlah 78 pasien $(81,25 \%)$ dan laki-laki 18 pasien $(18,75 \%)$. Usia rata-rata lakilaki lanjut usia dalam penelitian ini adalah 70 tahun dan wanita adalah 61,14 tahun. Data mengenai usia dan jenis kelamin pada lanjut usia dapat dilihat pada tabel berikut ini:

Tabel 4. Distribusi lanjut usia menurut jenis kelamin dan usia

\begin{tabular}{|l|l|l|}
\hline Jenis Kelamin & $\mathrm{n}$ & $\%$ \\
\hline Laki-laki & 18 & $18,75 \%$ \\
\hline perempuan & 78 & $81,25 \%$ \\
\hline
\end{tabular}

\section{Hasil Pemeriksaan Darah}

Pada penelitian ini ada enam parameter pemeriksaan yang digunakan untuk mendiagnosa anemia, yaitu kadar Hemoglobin, nilai hematokrit, jumlah eritrosit, $\mathrm{MCV}, \mathrm{MCH}$ dan $\mathrm{MCHC}$. Tabel berikut ini akan menjelaskan prefalensi hasil pemeriksaan berdasarkan data hasil pemeriksaan di laboratorium Hematologi Poltekkes Analis Kesehatan Yogyakarta dengan metode pemeriksaan hematologi otomatis:

Tabel 5. Distribusi nilai laboratorium diagnostik anemia pada Lanjut Usia di PSTW Abiyoso Yogyakarta

\begin{tabular}{|l|c|l|l|l|}
\hline \multirow{2}{*}{ Parameter pemeriksaan } & \multicolumn{2}{|c|}{ Normal } & \multicolumn{2}{c|}{ Tidak normal } \\
\cline { 2 - 5 } & $\mathrm{n}$ & \multicolumn{1}{c|}{$\%$} & $\mathrm{n}$ & $\%$ \\
\hline Kadar Hemoglobin & 65 & $67,71 \%$ & 31 & $32,29 \%$ \\
\hline Nilai hematokrit & 38 & $39,58 \%$ & 58 & $60,42 \%$ \\
\hline Jumlah eritrosit & 59 & $61,46 \%$ & 37 & $38,54 \%$ \\
\hline MCV & 78 & $81,25 \%$ & 18 & $18,75 \%$ \\
\hline MCH & 90 & $93,75 \%$ & 6 & $6,25 \%$ \\
\hline MCHC & 76 & $79,17 \%$ & 20 & $20,83 \%$ \\
\hline
\end{tabular}

Berdasarkan tabel di atas di ketahui bahwa data laboratorium dengan parameter pemeriksaan kadar $\mathrm{Hb}, \mathrm{MCV}, \mathrm{MCH}$ dan MCHC pada pasien lansia di PSTW Abiyoso Yogyakarta memiliki prefalensi yang lebih tinggi pada hasil yang normal dibandingkan dengan hasil yang tidak normal, sedangkan pada parameter pemeriksaan nilai hematokrit dan jumlah eritrosit menunjukkan bahwa sebagian besar pasien lanjut usia memiliki nilai hematokrit dan jumlah ertrosit yang tidak normal.

\section{Gambaran Anemia}

\subsection{Kejadian Anemia pada Lanjut Usia di PSTW Abiyoso}

Penelitian ini meliputi 96 pasien lanjut usia dengan usia 60 tahun ke atas. Hasil penelitian menunjukkan bahwa lanjut usia di PSTW Abiyoso ada yang anemia dan ada juga yang 
tidak anemia yang ditandai secara laboratorium melalui pemeriksaan kadar
Hemoglobin. Lebih jelasnya distribusi status anemia dapat dilihat pada tabel berikut:

Tabel 6. Distribusi status anemia berdasarkan kadar Hemoglobin

\begin{tabular}{|l|l|l|l|}
\hline \multicolumn{2}{|l|}{ Anemia } & \multicolumn{3}{|l|}{ Tidak Anemia } \\
\hline $\mathrm{N}$ & $\%$ & $\mathrm{n}$ & $\%$ \\
\hline 31 & $32,29 \%$ & 65 & $67,71 \%$ \\
\hline
\end{tabular}

Distribusi Anemia Berdasarkan Kadar Hb

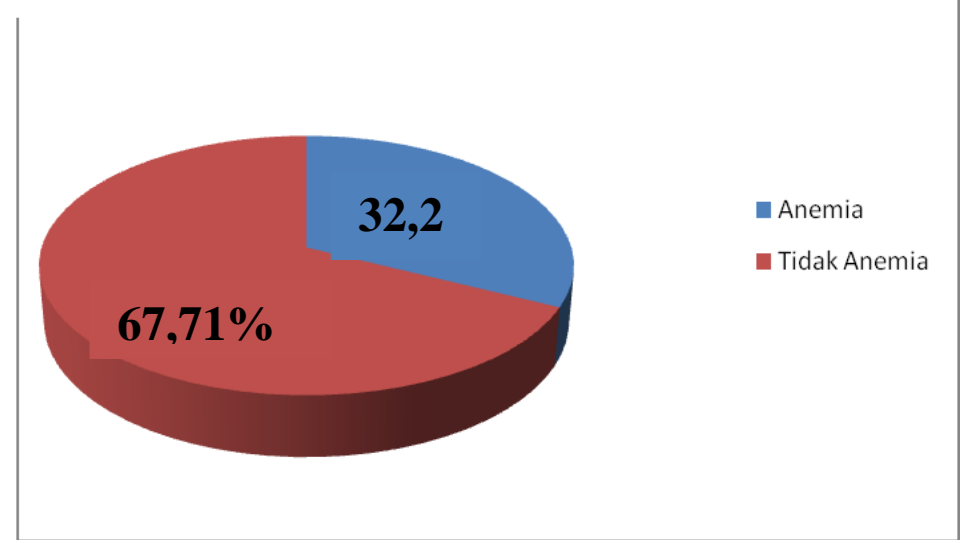

Gambar 4. Diagram distribusi Anemia pada Lanjut Usia di PSTW Abiyoso Yogyakarta (2013)

Diagram di atas menunjukkan bahwa status anemia pada pasien lanjut usia yang anemia sebanyak 31 pasien atau $32,29 \%$, sedangkan yang tidak anemia sebanyak 65 pasien yaitu $67,71 \%$.

\subsection{Derajat Anemia}

Berdasarkan hasil penelitian didapatkan derajat anemia pada pasien lanjut usia bervariasi. Berikut ini adalah tabel distribusi derajat anemia pada pasien lanjut usia di PSTW Abiyoso Yogyakarta:

Tabel 7. Distribusi derajat anemia

\begin{tabular}{|c|c|c|}
\hline $\begin{array}{c}\text { Derajat } \\
\text { Anemia }\end{array}$ & Frekuensi & Prosentase (\%) \\
\hline Ringan & 27 & $72,97 \%$ \\
\hline Sedang & 10 & $27,03 \%$ \\
\hline Berat & 0 & $0 \%$ \\
\hline Jumlah & 37 & $100 \%$ \\
\hline
\end{tabular}

\section{Distribusi Derajat Anemia}

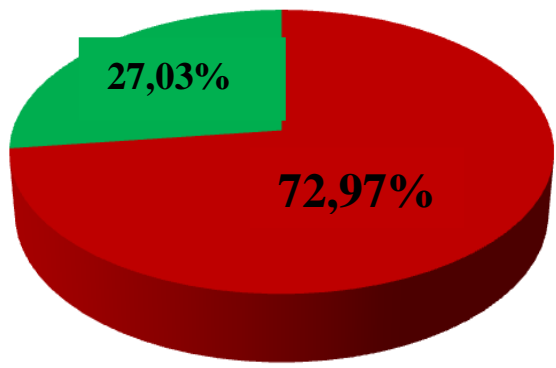


Dilihat dari distribusi diatas diketahui derajat anemia paling banyak terdapat pada tingkat anemia ringan yaitu 27 pasien atau $72,97 \%$, anemia sedang sebanyak 10 pasien atau $27,03 \%$.

\subsection{Gambaran Morfologi Eritrosit}

Pada penelitian ini diklasifikasikan juga anemia berdasarkan morfologi eritrositnya, berdasarkan hasil pemeriksaan indeks eritrosit. Untuk lebih jelas dapat dilihat pada table berikut ini:

Tabel 8. Distribusi anemia berdasarkan morfologi eritrosit

\begin{tabular}{|l|l|l|}
\hline Klasifikasi anemia & Frekuensi & Prosentase (\%) \\
\hline Mikrositik Hipokromik & 12 & $12,5 \%$ \\
\hline Normositik Normokromik & 84 & $87,5 \%$ \\
\hline Makrositik & 0 & $0 \%$ \\
\hline Jumlah & 96 & $100 \%$ \\
\hline
\end{tabular}

\section{Distribusi Anemia berdasarkan morfologi eritrosit}

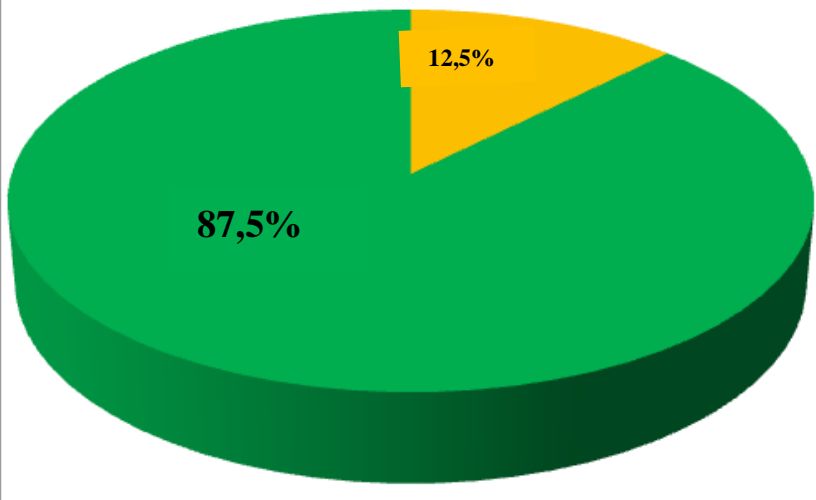

Hipokromik

Mikrositik

normokromik

Normositik

- Makrositik

Gambar 5. Diagram Distribusi Derajat Anemia pada Lanjut Usia di PSTW Abiyoso Yogyakarta (2013)

Diagram distribusi diatas menjelaskan prosentase morfologi anemia pada pasien lanjut usia. Diketahui distribusi terbanyak terdapat pada morfologi anemia normokromik normositik yaitu $87,5 \%$ dan morfologi anemia hipokromik mikrositik sebanyak $12,5 \%$.

\section{B. Pembahasan}

Penelitian pada tanggal 14-15 mei 2013 dilakukan untuk mengetahui gambaran anemia pada lanjut usia di panti sosial tresna werdha Abiyoso Yogyakarta. Sebagian besar sampel adalah lanjut usia berumur 60 tahun ke atas dengan rata-rata usia 74,28 tahun, dimana usia termuda 62 tahun dan tertua 94 tahun. Usia rata-rata laki-laki adalah 70 tahun, sedangkan wanitanya 61,14 tahun.

Anemia adalah suatu keadaan dimana jumlah Hemoglobin dalam darah kurang dari normal. Zat ini dibuat di dalam sel darah merah, sehingga Anemia dapat terjadi baik karena sel darah merah mengandung terlalu sedikit hemoglobin maupun karena jumlah sel darah yang tidak cukup (Umiyarni, 2013).

Anemia sering dijumpai pada lansia dan meningkatnya insidensi anemia dihubungkan dengan bertambahnya usia telah menimbulkan spekulasi bahwa penurunan hemoglobin kemungkinan merupakan konsekuensi dari pertambahan usia. Untuk mengetahui seorang lanjut usia telah menderita anemia, pemeriksaan laboratorium diagnostik untuk anemia memang sangat membantu. Pada penelitian ini saya menggunakan pemeriksaan yang sederhana dalam menegakkan diagnosis anemia, beberapa pemeriksaan laboratorium yang dilakukan adalah pemeriksaan kadar $\mathrm{Hb}$, nilai Hematokrit, Jumlah Eritrosit dan Indeks Eritrosit. Dari data pemeriksaan laboratorium 
diperoleh hasil lanjut usia yang mempunyai kadar $\mathrm{Hb}$ dibawah normal ada $32,29 \%$, nilai hematokrit yang tidak normal sejumlah $60,42 \%$, jumlah eritrosit yang rendah $38,54 \%$ dan pemeriksaan indeks eritrosit sebagian besar lanjut usia menderita anemia normositik normokromik $(87,5 \%)$ sedangkan yang anemia mikrositik hipokromik sebesar $12,5 \%$.

Kejadian anemia pada lanjut usia sebesar $23,96 \%$, pada laki-laki $72,22 \%$ sedangkan pada pasien perempuan sebesar $23,08 \%$. Dari suatu hasil studi dilaporkan bahwa prevalensi anemia pada laki-laki lanjut usia lebih besar dibandingkan lanjut usia perempuan, hal ini belum diketahui secara pasti penyebabnya karena belum ada penelitian lebih lanjut mengenai anemia pada lanjut usia berdasarkan jenis kelamin. Sementara penyebab dari anemia yang terjadi pada lanjut usia ini sendiri tidak diketahui secara pasti penyebabnya. Kemungkinan anemia yang terjadi pada pasien lanjut usia di panti sosial tresna werdha Abiyoso karena penurunan fungsi organ-organ tertentu pada tubuh lanjut usia, terutama pada saluran pencernaan. Jumlah gigi pada lanjut usia sering berangsurangsur berkurang serta terjadi penurunan produksi air liur, hal ini menyebabkan lanjut usia sulit untuk mencerna makanan serta akan membatasi jenis makanan yang dimakan. Makanan yang masuk ke lambung dengan pencernaan yang tidak sempurna dapat menyebabkan kerusakkan pada lambung, sehingga terjadi perdarahan pada lambung, semakin lama pardarahan akan menjadi kronis sehingga menyebabkan anemia. Selain itu penurunan fungsi saluran pencernaan dapat menyebabkan berkurangnya absorbsi zat-zat gizi penting dari makanan seperti zat besi, vitamin B12, kalsium, folat dan lain-lain.

Data penelitian menunjukkan bahwa derajat anemia pada lanjut usia di panti sosial tresna werdha Abiyoso Yogyakarta adalah anemia ringan $72,97 \%$ dan anemia sedang $27,03 \%$. Status derajat anemia ini tidak diketahui secara pasti penyebabnya, namun berdasarkan teori yang mengatakan anemia sering dijumpai pada lanjut usia dan meningkatnya insidensi anemia dihubungkan dengan bertambahnya usia telah menimbulkan spekulasi bahwa penurunan hemoglobin kemungkinan merupakan konsekuensi dari pertambahan usia, sehingga anemia ringan sering ditemukan pada lanjut usia.

Penelitian ini dilihat juga klasifikasi anemia berdasarkan morfologi eritrosit. Penelitian Suryadi Panjaitan menunjukkan bahwa gambaran morfologi darah tepi anemia penyakit kronik pada lanjut usia biasanya adalah normositik-normokromik atau mikrositik ringan, sedangkan anemia defisiensi besi adalah mikrositik-hipokromik. Dari data yang diperoleh diketahui sebagian besar pasien lanjut usia memiliki klasifikasi anemia mikrositik hipokromik yaitu sebesar $12,5 \%$ dan anemia normositik-normokromik sebanyak $87,5 \%$. Anemia mikrositik hipokromik adalah anemia yang terjadi akibat defisiensi besi dalam gizi atau hilangnya darah secara lambat dan kronik (blog keperawatan, 2011). Anemia normositik-normokromik adalah anemia yang disebabkan oleh disfungsi sumsum tulang sedemikian sehingga sel-sel darah yang mati tidak diganti atau disebut juga anemia aplastik yang disebabkan oleh banyak hal termasuk kanker sumsum tulang, pengrusakan sumsum tulang oleh proses autoimun, defisiensi vitamin, berbagai obat dan radiasi atau kemoterapi. Berdasarkan data penelitian kasus anemia mikrositik hipokromik pada lanjut usia disebabkan oleh kurangnya asupan nutrisi. Seiring dengan pertambahan usia, terjadi perubahan-perubahan di dalam tubuh manusia yang bersifat degeneratif (menurun fungsinya), penurunan fungsi pada saluran pencernaan menyebabkan berkurangnya absorbsi zat gizi penting dari makanan terutama zat besi. Perubahan pada tubuh lansia yang bersifat irreversibel (tidak dapat menjadi normal kembali) menyebabkan kerusakan pada sumsum tulang sehingga terjadi penurunan produksi sel eritrosit menyebabkan kekurangan hemoglobin dalam tubuh lanjut usia maka terjadi anemia.

\section{KESIMPULAN DAN SARAN}

Simpulan

1. Kasus anemia pada lanjut usia di Panti Sosial Tresna Werdha Abiyoso Yogyakarta sebesar $23,96 \%$ menderita anemia.

2. Anemia yang terjadi pada lanjut usia tersebut adalah anemia tingkat ringan sebesar $72,97 \%$ dan anemia sedang sebesar $27,03 \%$.

3. Klasifikasi anemia berdasarkan morfologi pada lanjut usia di Panti Sosial Tresna Werdha Abiyoso Yogyakarta adalah anemia normokromik normositik $87,5 \%$ dan anemia hipokromik mikrositik sebesar $12,5 \%$.

\section{Saran}

1. Perlu adanya asupan nutrisi terutama makanan yang banyak mengandung zat-zat besi. 
2. Adanya pemeriksaan anemia secara berkala, sehingga derajat kesehatan para lanjut usia terpantau

\section{DAFTAR PUSTAKA}

Arsiman, 2004, Gizi dalam Daur Kehidupan, Jakarta. Buku Kedokeran EGC.

Arikunto S, 1998, Prosedur Penelitian Suatu Pendektan Praktek, Rineka Cipta.Jakarta

Bahtari, I., 2010, Anemia Sebagai Faktor Risiko Penurunan Status Fungsional Pada Usia Lanjut Di Panti Wredha Daerah Istimewa Yogyakarta. Tesis, Jurusan IImu Kedokteran Klinik Universitas Gadjah Madah Yogyakarta.

Constantinides, P., 1994, General Pathobiology, USA: Appleton \& Lange.Notoatmodjo, S., 2007, Kesehatan Masyarakat IImu \& Seni, Rineka Cipta, Jakarta, Hal. 275

Diah, J. E. S., "Pengaruh Pemberian Pisang Ambon (Family Musaceae) Terhadap Kadar Zat Besi (Fe) Darah Pada Lanjut Usia Di Panti Sosial Tresna Werdha Bangkalan", Jurnal Infokes STIKES Insan Unggul Surabaya, Hal : 1.

Dyah, U. P., 2011, Anemia, http://Dyahpurnamasari.blog.unsoed.ac.id/files /-2011/03/anemia, diambil pada tanggal 5 februari 2013, Yogyakarta.

Handayani dan Haribowo, 2008, Asuhan Keperawatan Pada Klien Dengan Gangguan Sistem Hematologi, Salemba Medika, Jakarta.
Kurniawan, I., 2011, "Iron Deficiency Anemia In The Elderly", Med J Indones, Vol.20 No.1, Edisi Desember 2011: 1 .

Kuwpidh, K., 2011, Analisis Darah Lengkap, http://labkesehatan.-

blogspot.com/2011/11/hitung-darahlengkap.html, 6 Maret 2013, Yogyakarta.

Nugroho. W (2000). Keperawatan Gerontik. Edisi 2. EGC. Jakarta.

Oehadian, A., 2012, "Pendekatan Klinis dan Diagnosis Anemia", Jurnal Continuing Medical Education, Vol. 39 No. 6, Edisi 2012.

Panjaitan, S, 2003, "Beberapa Aspek Anemia Penyakit Kronik Pada Lanjut Usia", Jurnal IImu Penyakit Dalam Fakultas Kedokteran Universitas Sumatera Utara.

Proverawati, A., 2011, Anemia dan Anemia Kehamilan, Nuha Medika, Yogyakarta, hal: 131.

Ridwan, 2012, "Gambaran Indeks Eritrosit Pada lbu Yang Baru Melahirkan Dengan Persalinan Normal Di Rumah Sakit Bersalin St Fatimah Makassar", Karya Tulis IImiah, Jurusan Analis Kesehatan Fakultas Kesehatan Masyarakat Universitas Indonesia Timur Makassar.

Wahyudi, N., 2010, Keperawatan Gerontik, Jakarta: EGC.

Wikipedia, 2013, Daftar angka harapan hidup menurut CIA World Factbook, http://id.wikipedia.org/wiki/Daftar negara men urut angka harapan hidup, diambil pada tanggal 5 februari 2013, Yogyakarta. 